\title{
Erratum to: Nocardioides soli sp. nov., a bacterium isolated from a mountain soil
}

\author{
Sathiyaraj Srinivasan · Sang-Seob Lee • \\ Jae-Jin Lee $\cdot$ Myung Kyum Kim
}

Published online: 10 July 2014

(C) Springer International Publishing Switzerland 2014

\section{Erratum to: Antonie van Leeuwenhoek (2014) DOI 10.1007/s10482-014-0191-7}

Subsequent to the publication of the above paper it has been brought to our attention that the species epithet proposed for the taxon represented by strain $\mathrm{SR}-1^{\mathrm{T}}$ $\left(=\right.$ KEMC $\left.9004-134^{\mathrm{T}}=\mathrm{JCM} 19684^{\mathrm{T}}\right)$ is illegitimate as the name Nocardioides soli was coincidentally proposed by Sun et al. (Int. J. Syst. Evol. Microbiol. 64:2047-2052, 2014) for a different taxon represented by strain $\mathrm{mbc}-2^{\mathrm{T}}\left(=\mathrm{KACC} 17152^{\mathrm{T}}=\right.$ CCTCC AB $2012934^{\mathrm{T}}$ ).

To avoid further confusion, we propose here the corrected name for the taxon represented by strain SR$1^{\mathrm{T}}\left(=\right.$ KEMC $\left.9004-134^{\mathrm{T}}=\mathrm{JCM} 19684^{\mathrm{T}}\right)$.

The online version of the original article can be found under doi:10.1007/s10482-014-0191-7.

S. Srinivasan · J.-J. Lee · M. K. Kim ( $₫)$

Department of Bio and Environmental Technology, College of Natural Science, Seoul Women's University, Seoul 139-774, Republic of Korea

e-mail: biotech@swu.ac.kr

S. Srinivasan

e-mail: sathiya.micro@gmail.com

S. Srinivasan $\cdot$ S.-S. Lee

Department of Life Science, Graduate School of Kyonggi University, 94-6 Iui-dong Yeongtong-gu, Suwon 433-760,

Republic of Korea

e-mail: sslee@kyonggi.ac.kr

\section{Description of Nocardioides montaniterrae sp. nov.}

Nocardioides montaniterrae (mon.ta.ni.ter'rae; L. adj. montanus, of a mountain; L. n. terra, soil; N.L. gen. n. montaniterrae, of mountain soil, where the type strain was isolated).

The description of the species is as given for "Nocardioides soli" in Srinivasan et al. (2014) Antonie van Leeuwenhoek 106 (DOI: 10.1007/ s10482-014-0191-7).

Cells are Gram-positive, aerobic, non-motile, and short-rod-shaped, about $0.5-0.7 \mu \mathrm{m}$ in width and $1.0-1.2 \mu \mathrm{m}$ in length. Colonies grown on NA (Difco) for 2 days are smooth, small and pale yellow in colour. Growth occurs at $15-37^{\circ} \mathrm{C}$ (optimum about $30^{\circ} \mathrm{C}$ ) but no growth observed below 10 or above $42^{\circ} \mathrm{C}$. Growth occurs at $\mathrm{pH}$ 6.0-9.0 with optimum growth at $\mathrm{pH} 7$. Cells tolerate up to $2 \% \mathrm{NaCl}(\mathrm{w} / \mathrm{v})$ with optimum growth with no $\mathrm{NaCl}$. Oxidase and catalase positive. Hydrolysis of Tween 80 and starch is positive but not casein. Growth is observed on R2A, LB and TSA media.

Negative in tests for nitrate reduction, indole production, glucose acidification, arginine dihydrolase and $\beta$ galactosidase; positive for urease, gelatinase and esculin hydrolysis in the API 20NE test. The following carbon sources are utilized in the API 20NE and API 32GN: acetate, $\mathrm{N}$-acetyl-D-glucosamine, adipate, L-alanine, Larabinose, gluconate, D-glucose, glycogen, L-histidine, 3-hydroxybenzoate, itaconate, D,L-lactate, D-mannose, phenyl acetate, propionate, D-ribose, L-serine and $n$ - 
valerate. Utilization of the following substrates is negative: caprate, citrate, L-fucose, $\beta$-galactosidase (PNPG), 4-hydroxybenzoate, D,L-3-hydroxybutyrate, 2-ketogluconate $(\alpha)$, 5-ketogluconate, L-malate, malonate, D-maltose, D-mannitol, D-melibiose, myo-Inositol, L-proline, L-rhamnose, salicin, D-sorbitol, suberate and D-sucrose.

In assays with API ZYM, acid phosphatase, cystine arylamidase, esterase (C4), esterase (C8), $\alpha$-fucosidase, $\alpha$-glucosidase, leucine arylamidase, naphthol-AS-BIphosphohydrolase, trypsin, and valine arylamidase are present, but $N$-acetyl- $\beta$-glucosaminidase, alkaline phosphatase, $\alpha$-chymotrypsin, $\beta$-galactosidase (ONPG), $\alpha$-galactosidase, $\beta$-glucosidase, $\beta$-glucuronidase, lipase
(C14) and $\alpha$-mannosidase are absent. Chemotaxonomic characteristics are the following. The predominant menaquinone is $\mathrm{MK}-8\left(\mathrm{H}_{4}\right)$ and major polar lipids are phosphatidylglycerol and diphosphatidylglycerol. The major cellular fatty acids are iso- $\mathrm{C}_{16: 0}, 10$-methyl- $\mathrm{C}_{18: 0}$, and $\mathrm{C}_{18: 1} \omega 9 c$. The DNA G+C content of the type strain is $72.4 \mathrm{~mol} \%$.

The type strain, SR $-1^{\mathrm{T}}\left(=\right.$ KEMC $9004-134^{\mathrm{T}}=\mathrm{JCM}$ $19684^{\mathrm{T}}$ ), was isolated from a mountain soil collected in Seoul Women's University at South Korea. The NCBI GenBank/EMBL/DDBJ accession number for the $16 \mathrm{~S}$ rRNA gene sequence of strain $\mathrm{SR}-1^{\mathrm{T}}$ is KF955611. 